\title{
Classification and Ideology--A Critical Discourse Analysis of Bush's Two Speeches on 911 Attack
}

\author{
Haicui Zheng ${ }^{1, *}$ \\ ${ }^{1}$ College of Foreign Languages, Inner Mongolia University, Huhhot, China \\ *Correspondence: College of Foreign Languages, Inner Mongolia University, Huhhot, 010070, China. E-mail: \\ zhenghaicui@yahoo.com
}

Received: January 14, 2015 Accepted: January 27, 2015 Online Published: February 14, 2015

doi:10.5430/wjel.v5n1p48 URL: http://dx.doi.org/10.5430/wjel.v5n1p48

\begin{abstract}
The beginning of the $21^{\text {st }}$ century witnessed a terrible event -911 attack in 2001 . Right after the attack, the then President George Bush delivered a speech. On the fifth anniversary, President Bush addressed the whole nation again. One salient linguistic feature in two speeches is classification. A critical discourse analysis of Bush's two speeches reveals Bush's deep-rooted ideology that America is the most powerful and dominant country in the world.
\end{abstract}

Keywords: critical discourse analysis; language and ideology; classification

\section{Introduction}

Many people think that the primary purpose of human language is to convey information. However, such kind of understanding of language is quite superficial. Language plays an important role in helping people understand the world. At the same time it influences and determines people's thinking and behavior unconsciously. Therefore, discourse is not just a tool of exchanging information between individuals, but an important form of social interaction, a social practice (Fairclough \& Wodak, 1997; Wodak et.al., 1999). Therefore a discourse analysis should not just focus on grammar, rhetoric, style, structure, etc. A critical way should be adopted to analyze the social, cultural, and political functions of a discourse (van Dijk, 1993). Simpson emphasizes that the motivating principle behind critical discourse analysis is "to explore the value system and sets of beliefs which reside in texts; to explore, in other words, ideology in language" (1993, p.5).

On the morning of September, 11th, 2001, hijacked jets destroyed the twin towers of the World trade Center and hit the Pentagon. Right after the attack, the then President George Bush delivered a speech. On the fifth anniversary, the then President Bush addressed the whole nation again. This paper aims to conduct a critical discourse analysis of Bush's first speech containing 598 words and second speech which has 2691 words with the classification as the focus, for it is unnecessary and impossible to explore all linguistic elements while doing critical discourse analysis (Xin, 2005, p.65), so as to reveal the hidden ideology and to help readers come to a better understanding of the American government's political decisions.

\section{Language and Ideology}

Natural world is known for its variety and richness. It is impossible for human beings to know everything in it. Language works as a medium in bridging the gap between the multitude of the world and the limitation of human beings. It helps people understand the world economically and efficiently. People can read or listen to others' reports of things that they do not know. However, this efficiency carries danger, because "before one person passes on knowledge to another, that knowledge has already been selected or shaped, intentionally or unintentionally, by the mind of the communicator" (Birk, et al., 1992). The very reason for this is that people live in an immensely diversified society, each individual is socialized into the experience of a particular section of society and the circumstances in which communication occurs bring forth very different modes of language and thought (Fowler, 1986). Therefore, the language used by different persons carries the user's social background. Even when their intentions are to write or speak objectively, the very facts and words they select slant their communications. So 
language is biased, and in a strict sense people cannot communicate without bias.

Language is biased because it actively gets involved in constructing and influencing people's opinions besides being used passively. However, there exists "a half-conscious belief that language is a natural growth and not an instrument which we shape for our own purpose" (Orwell, 1992, p.141). Though neglected by most ordinary people, the influence and power of language have not escaped the linguists' notice. Xin (2000) points out people's perceptions are undergoing by means of language and reinforced in language use, which are also constructing the social reality. Such kind of social construction is ideological in nature. Language is ideological in another sense: "it involves systemic distortion in the service of class interests and hence it is an instrument of control, as well as of communication" (Xin, 2000, p.36).

According to Fowler, ideology is "the ways in which people order and justify their lives"(1991b, p.92). Fairclough holds "ideology involves the representation of 'the world' from the perspective of a particular interest" (1995, p.44). Thomson argues that "ideology, broadly speaking, is meaning in the service of power" (1990, p.7). So Fowler tries to give a neutral definition of ideology, while Fairclough and Thomson focus more on ideology's political function. Simpson also believes "language can be used by powerful groups to reinforce their dominant ideology" (1993, p.6).

So language carries ideology, which, however, is often overlooked by both the writer/speaker and the reader/hearer. So people are influenced by ideology hidden in language unconsciously. Critical discourse analysis aims to denaturalize the ideology and make it crystal to the readers and listeners (Fairclough, 1995). For example, the two sentences "I feel cold" and "It's cold" mean almost the same to most readers. However, the first sentence comments directly on the speaker's own feeling, while the second attributes his/her discomfort to the outside world. Such an easy example shows that language reveals the speaker/ writer's attitude. It is also well known that the terms "Negroes", "blacks" or "Niggers" used to address black people have a strong ideological tendency.

In sum, though it creates and spreads knowledge, aids thinking and facilitates perception, language has two drawbacks: "the categories encoded in language may become fossilized and unconscious; and they may be the products and the tools of a repressive and inequitable society" (Fowler, 1986, p.34). The task of linguistic criticism or critical discourse analysis is to make a study on the linguistic forms exploited in a discourse with Halliday's systemic functional grammar as one of its main theoretical bases so as to reveal the relationship between language, power and ideology.

\section{Fowler and Kress's Framework}

In1970s critical linguistics was first put forward to reveal the ideology hidden in texts. Then critical linguistics was gradually developed into critical discourse analysis and different methods of critical discourse analysis have been put forward, which can be used in different contexts to interpret different discourses, for "there is no constant relationship between linguistic structure and its semiotic significance" (Fowler, 1991a, p.90).

Fowler and Kress (1979) suggested conducting critical analysis of texts from five main aspects: the grammar of transitivity, the grammar of modality, transformation, classification, coherence, order and unity. Here a very brief introduction will be made to their framework of critical discourse analysis.

According to Halliday (1994), a text or discourse has three metafunctions: ideational, interpersonal, and textual function. The transitivity system is used to realize the ideational function of a discourse. It construes the world of experience into a manageable set of process types: material, mental, relational, behavioral, verbal, existential processes. A process consists, in principle, of three components:

(i). The process itself;

(ii). Participants in the process;

(iii). Circumstances associated with the process.

(Halliday, 1994, p.107)

Fairclough claims that choosing which process to describe the real happening bears "important cultural, political or ideological meaning" (1992, p.180). For example, in 1985, when trying to arrest a man, an English policeman fired and killed the man's five-year-old boy. The event was reported on BBC TV news as "The boy died when the policeman's gun went off'. By such kind of description, the reporter conceals the agent of the act shooting, that is, the causer of the accident, consequently making it obscure who should take the responsibility. Besides the clause "when the policeman's gun went off" seems only to indicate the time when the accident happened. It seems it was 
the policeman's gun rather than the policeman that was responsible for the shooting. Analyzing language by means of transitivity can help readers think deeper and be alert to the ideology hidden in language.

Modality is one of the means to realize the interpersonal function of a discourse. Exploring modality shows the social and economic relationships between the persons involved in a conversation; the speakers/ writers' attitudes towards themselves, towards their interlocutors, and towards their subject and the actions performed through language (Fowler \& Kress, 1979). According to Halliday and Simpson, pronouns, content verbs, tense, direct speech, indirect speech all carry modality, in addition to modal verbs, modal adjectives and modal adverbs (cited in Xin, 1997). For example, the pronoun "we" is supposed to shorten the distance between the speaker/ writer and the listener/ reader. However, this is not the case. Sometimes it makes the addressees feel they are under others' influence and control. For example, "We know that's good for you" sounds a little aggressive. The addressees feel as if they have to accept the addresser's advice. What's more, the occurrence of the pronoun "you", and its frequency of occurrence are "measures of the speaker's consciousness of, care for, or most often, desire to manipulate, the addressees" (Fowler \& Kress, 1979, p.203). Therefore pronouns can sometimes be used to impose the writer/ speaker's will on the reader/ hearer and therefore should not be neglected in discourse analysis. Nor do other forms of modality such as tense, direct speech, indirect speech.

Among transformations, nominalizations and passivizations deserve special attention and close analysis. Nominalization refers to nominal expressions are used rather than sentences. It can weaken any feeling of activity by rendering a process as an object or a static state. Also modality and tense disappear in nominalization. Passivization has quite similar effect to nominalization. The objects that have been transformed into passive voice seem to be the agents, despite their real function as affected rather than affecting roles. "Processes, being under the control of agents, imply the possibility of modification, decision; whereas states are perceived as unalterable and thus to be put up with" (Fowler \& Kress, 1979, p.31). They also stress, "all 'be' forms classifying process as state are open to suspicion and should be inspected" (ibid). Look at the following examples:

1. The civilization is under threat.

2. The nuclear arms race is going on.

3. The women were denied the right to vote.

In the first two sentences, "threat" and "race", two verbs, are used as nouns. The dynamic processes are transformed into static states, a known fact that is not easy to be changed. Also the actors or the agents are concealed. No one knows who or what is threatening the civilization and who starts the nuclear arms race, as if they happen automatically, without any cause. In the third sentence, who denied the women's right is not expressed. Only a fact is given. Just as Simpson states, the use of the passive with agent deleted is one of the features of transitivity that is frequently used as a realization of ideology (1993, p.114). All these sentences are seemingly objective description. However, a lot of very important information has been neglected or ignored.

Classification refers to the describing or framing of the people or events involved. The choice of words in a discourse is the main representation of classification. When people choose to make a description, the words they choose to use in most cases are not objective enough to reveal the true nature of the things. "In Halliday's linguistic theory, vocabulary or lexis is a major determinant of ideological structure" (Fowler, 1991a, p.80). Language reflects people's thinking and it is also influenced by people's cognition and their feelings. Different attitudes to and opinions of things and events result in different choice of diction. Reah also asserts that lexical choice is one of the most powerful tools to construct ideology (1998, p.75-77). For example, millions of farmers were deprived of their farmland and sent trudging along the road. The authority called it "transfer of population" or "rectification of frontiers" (Fowler, 1986, p.33). The merciless exploitation was transformed into a great project. The readers cannot see how the local residents suffered from it. Critical discourse analysis aims to make readers more aware of the real fact and more sensitive to the writers' intention or unconscious ideology. Language reveals the speaker/ writer's thinking and their attitudes whether they choose their words intentionally or unintentionally. Make a study on classification throw some light on the relationship between language and ideology.

Coherence, order and unity are closely related with the textual function of a discourse. Cohesion is a kind of grammatical means used to achieve semantic unity. Coherence is usually implicit and cannot find in the language itself. Coherence is based on the context and pragmatic inference. Take the following dialogue as an example:

Riley: (Sharply) Give me that tape.

Brown: I haven't got one! 
Riley: My patience is not inexhaustible.

\section{------- Tome Stoppard, Enter a Free Man}

In the dialogue, "My patience is not inexhaustible" seems irrelevant to the previous sentences. However, every reader knows it is a perfect and coherent discourse. The last sentence conveys a lot of information: Riley does not believe Brown's answer; he is on the verge of losing temper; he is threatening Brown, etc. If Riley speaks all what he thinks, the dialogue may be redundant and not so effective. Making an analysis on coherence, order and unity not only show how the discourse achieves unity in textual level, but also reveals the speaker's real intention and attitude.

Above is a brief introduction to Fowler and Kress's framework of critical linguistics, which have been applied in some papers, theses or dissertations studying either transitivity (cf. Zhang, 2012, Wang, 2013; Zhang, 2014 ) or modality (cf. Gao, 2014). And transformation is mainly discussed as a section of critical discourse analysis while coherence analysis appears more in research about textual metafunction (cf. Zhang, 2012). Few studies on classification have been found.

Language use and discourse construction are very flexible. Each individual discourse has its own special features worthy of study. Classification is a salient characteristic in Bush's speeches. In the next part, the author will focus on analyzing classification in Bush's two remarks with an aim to show the American government's attitudes and its ideology.

\section{Classification and Ideology in Bush's Speeches}

On the morning of September $11^{\text {th }}$, the twin towers of the World Trade Center were destroyed by the hijacked jets and the Pentagon was hit as well. The event shocked the world. The then President Bush delivered a speech. On the fifth anniversary, Bush addressed the whole nation again, in which the attackers, the America and the Iraqi people were mentioned. Different adjectives, nouns and verbs are used to depict the two sides involved in the event, which is shown clearly in the following table:

\begin{tabular}{|c|c|c|c|}
\hline Word class & speech & The attackers & The U.S.A \\
\hline \multirow[t]{2}{*}{ adjective } & $1^{\text {st }}$ speech & deadly, evil, despicable & great, strong, powerful \\
\hline & $\begin{array}{l}2^{\text {nd }} \\
\text { speech }\end{array}$ & evil, tough, dangerous, terrible & good, free, confident, civilized \\
\hline \multirow[t]{2}{*}{ noun } & $1^{\text {st }}$ speech & $\begin{array}{l}\text { acts of terror, acts of mass murder, } \\
\text { terrorist attacks, the worst of human } \\
\text { nature }\end{array}$ & $\begin{array}{l}\text { victim, the brightest beacon, } \\
\text { justice }\end{array}$ \\
\hline & $\begin{array}{l}2^{\text {nd }} \\
\text { speech }\end{array}$ & $\begin{array}{l}\text { barbarity, horror, evil, enemy, } \\
\text { threats, terror, more terrible attacks, } \\
\text { remnants, tyranny }\end{array}$ & $\begin{array}{l}\text { victims, suffering, the entire free } \\
\text { world, extraordinary acts of } \\
\text { courage, courage ( } 3 \text { times), } \\
\text { freedom, strength, trust, } \\
\text { confidence, faith }\end{array}$ \\
\hline \multirow[t]{2}{*}{ verb } & $1^{\text {st }}$ speech & attack, shake, shatter, dent & protect, bring (them) to justice \\
\hline & $\begin{array}{l}2^{\text {nd }} \\
\text { speech }\end{array}$ & $\begin{array}{l}\text { murder, made war upon the entire } \\
\text { free world, kill without mercy, } \\
\text { destroy }\end{array}$ & $\begin{array}{l}\text { protect, resolve, bring you to } \\
\text { justice, kill or capture, making } \\
\text { great sacrifices, ensure, help, } \\
\text { unite, came to the aid }\end{array}$ \\
\hline
\end{tabular}

A quantitative study is not provided to calculate the frequency of the adjectives, nouns and verbs to be analyzed, because it is of little significance to compare the distribution of each word class among the whole speech for this is mainly a qualitative study. Furthermore only the adjectives, nouns and verbs concerning America and the attackers are under study.

As to how the classification reveals ideology, this paper will discuss it from four aspects: relexicalization, overlexicalization, the positioning of adjectives and other modifiers, and the choice between nouns and adjectives.

\subsection{Relexicalization}

"Relexicalization is relabelling, the provision of a new set of terms, either for the whole language or for a significant area of the language; it provides a new perspective for speakers, often in specialized areas which are distinct from 
those of the larger social group" (Fowler \& Kress, 1979, p.210).

In the first speech, Bush described the attack as "the acts of terror" and "terrorist attacks" to "acts of mass murder", the act becomes more and more serious, for the acts of murder involve law, courts, trials, sentencing, etc. The causers and all the people involved in the acts of murder must be punished according to the law, otherwise, it is unjust and the law is not strictly observed. If acts of terror are lesser crimes, acts of murder are heavy offense and acts of mass murder are more serious and therefore deserve more severe punishment. Later, Bush named the acts as "evil, the very worst of human nature", thus transforming a local crime into a universal action that should be condemned by the people all over the world. From the analysis of relexicalization, we can see Bush's anger and hatred to the attackers. What's more, by means of relexicalization, Bush made the attacking act of hijacked jets more and more severe, thus establishing gradually and naturally a good reason for the following vengeance action that the American government is going to start. Since the attackers are evil, to fight against them is fighting against evil. Therefore, the military actions are good and justified. Under the disguise of fighting against evil, lesser evils like curtailing individual liberties, sacrificing some countries' interest, and so on so forth are quite acceptable and tolerable, for all these are necessary for putting a noble ideal, namely, to bring the evil doers to justice and get rid of the worst of human nature, into reality.

Besides Bush used verbs "protect" and "bring (them) to justice" to describe the military action America was going to start. America is thus depicted as a policeman who protects its people and the military action is an exercise or enforcement of law. In this way the war is justified and beautified. In this way, Bush is also calling for the worldwide understanding, support, help, and even co-action. He did express such kind of wish directly in his remark, "American and our friends and allies join with all those who want peace and security in the world. And we stand together to win the war against terrorism".

In the second speech, Bush attached a new label of "barbarity" to the attackers and creates a sharp contrast between America as a civilized nation and attackers as uncivilized and barbarian. In such a way the reason why the America was the target of attack is attributed to the civilization and development of America. As he mentioned in the speech, the attackers are "radical dictators" who hate freedom and fear freedom.

As to the United States, Bush used "good", "free", "confident" and "civilized" to emphasize that America is developed and civilized country cherishing freedom and at the same time fill the American people with national pride and confidence. And verbs "protect" and "bring you to justice" were used again and achieved the same effect as in the first speech. Furthermore "kill or capture" is supposed to be the duty of policemen. Thus by taking military action, America is performing the policeman's duty. The phrase "came to the aid of neighbors in need" portrays the strength and generosity of America and at the same time enlists the supports of other countries. In Bush's two speeches, relexicalization helps him classify the involved parties in an implicit way and form a conception of the event under discussion, finally achieving the purpose of persuading and influencing the audience--the American people and even the world people.

\subsection{Overlexicalization}

According to Fowler \& Kress, "overlexicalization is the provision of a large number of synonymous or near-synonymous terms for communication of some specialized area of experience" (1979, p.211). The importance of overlexicalization in critical discourse analysis is that "it points to areas of intense preoccupation in the experience and values of the group which generates it, allowing the linguists to identify peculiarities in the ideology of that group"(ibid, p.212).

In Bush's first speech, "evil" and "despicable", especially "evil" was used several times to describe the attacking. These synonyms stress his feeling of anger and hatred, and to emphasize the evil nature of the attacking. He also used several verbs that are synonyms to describe the event. "Terrorist attacks can shake the foundation of our biggest buildings, but they cannot touch the foundation of America. These acts shattered steel, but they cannot dent the steel of American resolve." Such kind of synonyms was used to emphasize the effects of attacking: the attacks can only do some harm to the buildings of America and they cannot destroy the nation as a whole.

In the second speech, Bush used adjectives "evil", "terrible", "dangerous" and "tough" and nouns "horror", "terror", "evil" and "threat" to describe the attackers. These synonymous or near-synonymous words highlight the evil nature of the attacking and arouse people's antipathy or even hatred to the attackers. The synonymous expressions "help" and "came to the aid of neighbors in need" highlight the strength and generosity of America. The synonyms in "And we go forward with trust in that spirit, confidence in our purpose - and faith in a loving God who made us to be free" highlight the America's strong belief and determination. 
In conclusion, overlexicalization helps Bush to highlight the evil nature of the attackers and the power of America.

\subsection{Positioning of Adjectives and Other Modifiers}

The positioning of adjectives and other modifiers are highly revealing (Fowler \& Kress, 1979, p.212). If adjectives are placed after the copula words, they tend to declare that the statement is the writer/ speaker's subjective judgment. If they come before the nouns, they are integrated as a kind of attributives into the nominal phrases. For example, "The student is intelligent" appears to be the writer/ speaker's judgment or personal opinion, while "the intelligent student" tends to put the student into a kind of category. So "prenominal modification tends to indicate classification rather than evaluation" (ibid). In this way, the subjective opinions are changed into a kind of objective description.

In Bush's first speech, almost all what he used to refer to the attackers are prenominal modification, which is shown in descriptions like "evil, despicable acts of terror", "acts of mass murder", and "Today our nation saw evil, the very worst of human nature". As to the American government, most of the adjectives are placed after the copula words. For example, "Our country is strong", "We're the brightest beacon for freedom and opportunity in the world", "Our military is powerful", "Our financial institutions remain strong". From the striking contrast concerning the position of the modifiers, people can see clearly that Bush tends to emphasize the attackers are inherently evil. What's more, Bush has so strong confidence in the American government's power that he sounds domineering and aggressive.

In the second speech, Bush used both "adj+noun" and "noun +adj" structures like "more terrible attacks", "dangerous enemies" and "they are evil" and "Our enemies in Iraq are tough" to express his personal opinion on attackers. As to America, Bush used "free nations", "the entire free world" and "civilized nations". And he used "we can be confident" (twice) to express the American's government's confidence. So "free" and "civilized" tend to be the innate or definite attribute of America.

\subsection{Choice between Nouns and Adjectives}

According to Xin (1997), what adjectives and verbs depict does not last forever. Usually the characteristics given by adjectives and verbs are dynamic, temporary and ready to change. However, nouns tend to attach permanent features to the persons or things being discussed. The difference between "Don't be foolish" and "Don't be a fool" is quite obvious.

Seen from the previous table, nouns are more preferred than adjectives in Bush's two speeches. In the first speech, "evil" as noun, "acts of terror", "acts of mass murder" and "the very worst nature of human nature" are used to describe the attacking. For America, Bush classified it as "victim" and at the same time declared"we are the brightest beacon for freedom and opportunity in the world". Such kind of framing clearly shows Bush's attitudes. The word order--adjective + noun and the superlative in the metaphor AMERICA IS BEACON throws some light on the American government's ideological tendency. According to Bush, the attackers are evil by nature. It seems they are born to attack others. They are murderers and should be sent to the hell. People all over the world should stand together with America to fight against these people.

In the second speech, Bush repeated the word "victim" and mentioned America's "suffering". Furthermore, Bush described America as "the entire free world" and praised American people's courage by the phrase "extraordinary acts of courage" and the repetition of "courage" (three times). In the end, Bush tried to boost American people's morale with "strength" and the synonyms "trust", "confidence" and "faith".

\subsection{Summary and Interpretation}

The above is a critical analysis of Bush's two speeches addressed to the nation on the terrorist attack. The choosing and ordering of the diction in Bush's remarks are highly revealing. The analysis focuses on the classification, which is tackled from four aspects: relexicalization, overlexicalization, the positioning of adjectives and other modifiers, and the choice between nouns and adjectives. Relexicalization provides readers with perspectives of looking at the matter under discussion and influences them unconsciously. Overlexicalization or the appearance of many synonyms or near-synonymous terms reveals the value orientation or ideology of the speaker or writer (Tian, 2014: 67). The choice between adjectives and nouns and the arrangement of their order are also highly revealing. Bush's attitude and the then American government's ideology are revealed through the critical analysis of these linguistic elements.

In two speeches, Bush labeled America as "victim" and described America's military action as "bring them to justice" and "protect" the American people. Such classification leads people to think in such a logic that since America is the victim and it is great and strong, the American government has to take military action and is capable of defeating the attackers. Thus the military reaction is necessary and justified. Bush labeled America as "the free nation", "the civilized nation", "the brightest beacon for freedom and opportunity in the world" and attributed the reason why 
America was attacked to America's freedom and civilization. Bush stated directly, "America was targeted for attack because we are the brightest beacon for freedom and opportunity in the world. And no one will keep that light from shining". That's just the important part of the American government's ideology and its consistent diplomatic policy. They advocate the American government is the most democratic government where freedom is valued and well preserved. All people are born equal and can equally enjoy the opportunity. However, a well-known fact is that for a long time the black people and the American Indians have been struggling for equal rights and opportunities as their white counterparts. Despite this, the American government still declares they do better than any other country in the world and therefore they are "the brightest beacon for freedom and opportunity in the world". They are also determined to be the beacon forever, for Bush said, "no one will keep that light from shining". Under the guidance of such kind of ideology, the American government actively got involved in many things in the world, such as Iran-Iraq War, and interfered in many countries' domestic affairs, such as the conflict happened in Yugoslavia. And many people have become victims due to America's military reaction to the attacking and America's military interference in the name of "protecting human rights and preserving world peace". In many cases, America acted as a world policeman and ignored the role of international organization such as UN Security Council. All these contribute to the reason why the American government was hated. The 911 attack was intended to give a big blow to the American government, for the twin towers of the World Trade Center are the symbol of the American economy and the Pentagon was the image of American military power.

A critical analysis of Bush's two speeches reveals the hidden ideology of Bush Administration that America is the innocent victim which is attacked just because America is the brightest beacon in the world where freedom is cherished and opportunity is given. As "the brightest beacon", America can guide and lead the world. With such an ideology, Bush started the war which, however, put the Bush Administration into both approval and opposition at home and in the international world.

\section{Conclusion}

Critical linguistics is one of the important ways of analyzing a text. It focuses on linguistic analysis while critical discourse analysis, based on critical linguistics, moves into a broader horizon and does an interdisciplinary study by absorbing some theories from sociology (Tian, 2014). This study first makes an analysis of Bush's two speeches with Fowler and Kress's framework of critical linguistics and then moves into critical discourse analysis and gives an interpretation of the two speeches to reveal the interaction between language and ideology, how these two are influenced and determined by the social structure and power and how they are used to serve a certain group of people in a society. Consequently texts are not static linguistic products but a social practice which influences and participates in social construction (Fairclough \& Wodak, 1997; Wodak et.al., 1999). Making a critical discourse analysis makes people more aware of the difference between the fact and the personal opinion and make them sensitive to the ideology that is often normalized and therefore easily overlooked. The ultimate purpose of this paper is to arouse the readers' awareness of language's function so as to develop a critical eye to the language use.

\section{References}

Birk, N., \& Birk, G. (1992). Selection, slanting, and charged language. In Goshgarian, G. (Ed.), Exploring Language (pp. 113-121). New York: HarperCollins Publishers.

Fairclough, N. (1992). Discourse and Social Change. Cambridge: Polity Press.

Fairclough, N. (1995). Critical Discourse Analysis: The Critical Study of Language. London/ New York: Longman.

Fairclough, N., \& Wodak, R. (1997). Critical discourse analysis. In van Dijk. T. A. (ed.), Discourse as Social Interaction. London: Sage.

Fowler, R. (1986). Linguistic Criticism. Oxford: Oxford University Press.

Fowler, R. (1991a). Language in the News: Discourse and Ideology in the Press. London/ New York: Routledge.

Fowler, R. (1991b). Critical linguistics. In K. Malmkjoer (Ed.), The Linguistics Encyclopedia. London: Routledge.

Fowler, R., \& Kress, G. (1979). Rules and regulations. In Fowler, R., Hodge, B., Kress, G., \& Trew, T. (Eds.) Language and Control (pp.26-45). London: Routledge \& Kegan Paul.

Fowler, R., \& Kress, G. (1979). Critical linguistics. In Fowler, R., Hodge, B., Kress, G., \& Trew, T. (Eds.) Language and Control (pp.185-213). London: Routledge \& Kegan Paul. 
Gao, Ying. (2014). A Critical Discourse Analysis of Obama's Victory Speech in 2012 under the Appraisal Theory. MA Thesis. Inner Mongolia University.

Halliday, M.A.K. (1994/ 2000). An Introduction to Systemic Functional Grammar. London: Edward Arnold/ Beijing: Foreign Language Teaching and Research Press.

Orwell, G. (1992). Politics and the English language. In Goshgarian, G. (Ed.). Exploring Language. New York: HarperCollins Publishers.

Reah, D. (1998). The Language of Newspapers. London: Routledge.

Simpson, P. (1993). Language, Ideology and Point of View. London/ New York: Routledge. http://dx.doi.org/10.4324/9780203312612

Tian, Hailong. (2014). Critical Discourse Analysis: Interpretations, Reflections, and Applications. Tianjin: Nankai University Press.

Thompson, J. (1990). Ideology and Modern Culture. Cambridge: Polity Press.

van Dijk, T. A. (1993). Principles of critical discourse analysis. Discourse \& Society, 4(2), 249-283. http://dx.doi.org/10.1177/0957926593004002006

Wang, Ning. (2013). A critical analysis of Chinese and western network news headlines from the perspective of transitivity. Journal of Changzhou University (Social Science Edition), 14(6), 74-77, 93.

Wodak, R., Cilla, R., de, Reisigl, M., \& Liebhart, K. (1999). The Discursive Construction of National Identities (Trans. Angelia Hirsch \& Richard Mitten). Edinburgh: Edinburgh University Press.

Xin, Bin. (1997). On critical discourse analysis of English discourse. Journal of Sichuan International Studies University Foreign Language, 4, 43-49.

Xin, Bin. (2000). Intertextuality from a Critical Perspective. Suzhou: Suzhou University Press.

Xin, Bin. (2005). Critical Linguistics: Theories and Applications. Shanghai: Shanghai Foreign Language Education Press.

Zhang, Guanqun. (2014). Critical Discourse Analysis of Transitivity in TV Talk Shows-A Case Study of HARD talk. MA Thesis. Lanzhou University of Technology.

Zhang, Shubin, \& Zhang Xiaoxin. (2012). A transitivity approach to English neutral news. Journal of Hebei University (Philosophy and Social Science), 37(2), 149-151.

Zhang, Xiao. (2012). Cause-consequence relations in English discourse. Foreign Language Research, 167(4), 96-99. 